JAMP: Jurnal Adminitrasi dan Manajemen Pendidikan Volume 2 Nomor 3 September 2019, Hal : 126-135

Tersedia Online di http://journal2.um.ac.id/index.php/jamp/ ISSN 2615-8574 (online)

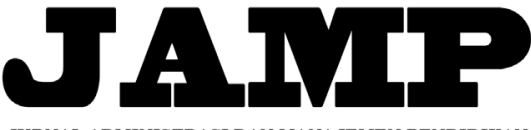

JURNAL ADMINISTRASI DAN MANAJEMEN PENDIDIKAN

\title{
PENGELOLAAN USAHA MANDIRI SEKOLAH DALAM PENINGKATAN KUALITAS PENDIDIKAN
}

\author{
Angga Kurniawan \\ Maisyaroh \\ Djum Djum NoorBenty
}

\author{
Universitas Negeri Malang - Jalan Semarang No.5 Malang \\ Email: angga.kur68@gmail.com
}

\begin{abstract}
The purpose of this study is to provide the information of management school independent businesses in school. This research used the qualitative approach with case studies types. Data collection tecniques used are interviews, observation, and documentation. The process of data analysis are data condensation, data display, and conclusion drawing/ verification. The result of this research: there are 3 types of school independent businesses, namely school waste banks, business center school, and car air conditioning workshops; has collaboration with the industries namely Bank Sampah Malang, eSWe, Aice, Unggul, and Auto 2000; school independent businesses impacts are school be famous, the needs of students and school residents are fulfilled, and school has the tools and location for practice; the supporting factors of the school independent businesses are based on the need relating to late payment of tuition fees, learning and teaching processes, and government programs, inhibiting factors of the school independent business are the arrival of the rainy season and holiday, violations committed, and the administration system that not good enough, and the solution used are by temporarily closing independent school businesses, do the supervising, and fix thesystem.
\end{abstract}

Keywords: management, school independent business

\begin{abstract}
Abstrak: Tujuan penelitian ini adalah memberikan informasi pengelolaan usaha mandiri di sekolah. Penelitian ini menggunakan pendekatan kualitatif dengan jenis penelitian studi kasus. Teknik pengumpulan data berupa wawancara, observasi, dan dokumentasi. Proses analisis data dengan data condensation, data display, dan conclusion drawing/verification. Hasil penelitian ini: terdapat 3 jenis usaha mandiri sekolah yaitu bank sampah sekolah, business center school, dan bengkel AC mobil; menjalin kerjasama dengan pihak industri yaitu Bank Sampah Malang, eSWe, Aice, Unggul, dan Auto 2000; dampak usaha mandiri sekolah yaitu sekolah menjadi terkenal, kebutuhan peserta didik dan warga sekolah terpenuhi, serta memiliki alat dan lokasi untuk praktik; faktor penunjang usaha mandiri sekolah yaitu adanya keterlambatan pembayaran SPP, kebutuhan peserta didik dan warga sekolah, dan program pemerintah; faktor penghambat usaha mandiri sekolah yaitu datangnya musim hujan dan liburan, adanya pelanggaran, dan sistem administrasi yang kurang baik; dan solusi yang dilakukan yaitu dengan cara menutup sementara usaha mandiri sekolah, melakukan pengawasan, dan memperbaikisistem.
\end{abstract}

Kata Kunci: pengelolaan, usaha mandiri sekolah

Usaha memajukan sekolah menjadi sekolah yang berkualitas merupakan salah satu kegiatan yang positif. Untuk melancarkan kegiatan ini tentu dibutuhkan banyak hal yang mampu mendukung kemajuan tersebut. Meningkatkan kualitas pendidik, sarana dan prasarana, serta menambah kegiatan-kegiatan yang lebih bermanfaat dapat menjadi hal yang perlu diperhatikan dalam memajukan sekolah menjadi sekolah yang lebih berkualitas. Dan untuk itu, sekolah membutuhkan banyak dana untuk memperlancar segala usaha dalam memajukan sekolah. 
Sekolah Menengah Kejuruan Negeri 6 Kota Malang memiliki sumber pemasukan yang dapat membantu peningkatan kualitas sekolah. Pemasukan-pemasukan tersebut seperti dana Anggaran Pendapatan dan Belanja Negara (APBN) dan Anggaran Pendapatan dan Belanja Daerah (APBD), serta kerjasama dengan pihak luar seperti Dunia Usaha/Dunia Industri (DU/DI). Sumber-sumber tersebut dapat menjadi modal SMKN 6 Kota Malang untuk memajukan sekolah menjadi sekolah yang lebihberkualitas.

Sekolah Menengah Kejuruan Negeri 6 Kota Malang yang memiliki banyak peserta didik tentunya memerlukan biaya yang lebih dalam usaha memajukan sekolah menjadi sekolah yang lebih berkualitas. Untuk itu, usaha mandiri sekolah menjadi solusi dalam menambah pemasukan keuangan SMKN 6 Kota Malang. Dengan demikian, pemasukan keuangan sekolah akan bertambah dan segala usaha dalam memajukan sekolah menjadi sekolah yang lebih berkualitas akan terlaksana.

Aspek pembiayaan (financing) merupakan aspek yang sangat penting dalam keberlangsungan pendidikan di suatu sekolah. Dalam konsep bisnis, aspek ini sangat menentukan keuntungan dan keberlangsungan sebuah lembaga (Barnawi \& Arifin, 2013). Oleh karena itu, dengan adanya usaha mandiri sekolah diharapkan pemasukan keuangan SMKN 6 Kota Malang dapat bertambah sehingga segala kebutuhan dan proses belajar mengajar dapat berjalan dengan baik.

Upaya mendirikan usaha mandiri sekolah tidak hanya digunakan untuk menambah pemasukan keuangan sekolah saja. Usaha mandiri sekolah juga didirikan untuk menunjang peningkatan kualitas pendidikan. Kualitas pendidikan tersebut dapat dilihat dari manfaat yang diberikan oleh usaha mandiri sekolah, baik secara umum maupun khusus. Secara umum, manfaat dari adanya usaha mandiri sekolah adalah terciptanya keseimbangan keuangan antara pemasukan dan pengeluaran sekolah. Hal tersebut juga dapat membuat kebutuhan-kebutuhan yang menunjang jalannya pendidikan terpenuhi dan dapat berjalan dengan baik. Kemudian secara khusus, manfaat dari adanya usaha mandiri sekolah adalah menciptakan kepuasan warga sekolah terhadap fasilitas (usaha mandiri sekolah) yang dapat dimanfaatkan secara optimal. Hal tersebut juga berkaitan dengan keberlangsungan proses belajar dan mengajar di dalam sekolah. Selain itu, sekolah akan dipandang memiliki eksistensi dan relevansi dengan kebutuhan yang ada di masyarakat.

\section{METODE}

Pendekatan yang digunakan dalam penelitian ini adalah pendekatan kualitatif dengan jenis penelitian studi kasus. Prosedur pengumpulan data dilakuan dengan menggunakan teknik wawancara, observasi, dan dokumentasi. Proses analisis data menggunakan data condensation, data display, dan conclusion drawing/verification. Pemeriksaan keabsahan data dalam penelitian ini dilakukan dengan cara triangulasi data, kecukupan bahan referensi, perpanjangan waktu pengamatan, dan pengecekan anggota.

\section{HASIL}

\section{Jenis Usaha Mandiri Sekolah di SMKN 6 Kota Malang}

SMKN 6 Kota Malang memiliki beberapa usaha mandiri sekolah, yaitu bank sampah sekolah, business center school, dan bengkel Air Conditioning (AC) mobil. Banyaknya sampah di sekitar dan ketidakpedulian masyarakat terhadap lingkungan menjadi salah satu faktor didirikannya bank sampah sekolah. Selain itu, banyaknya peserta didik di SMKN 6 Kota Malang yang tidak bisa membayar SPP tepat waktu juga menjadi faktor didirikannya bank sampah sekolah. Dengan adanya bank sampah sekolah, peserta didik dapat menabung sampah dan ditukar dengan uang, sehingga uang tersebut dapat digunakan untuk membayar SPP dan kebutuhanlainnya.

Business Center School (BCS) milik SMKN 6 Kota Malang merupakan pusat bisnis sekolah yang bergerak pada bidang produksi, jasa, dan persewaan. Terdapat 3 jenis usaha yang dimiliki oleh BCS SMKN 6 Kota Malang, yaitu Unit Produksi dan Jasa (UPJ), kantin sekolah, dan persewaan mobil. 
Ketiga usaha tersebut dimanfaatkan untuk memenuhi kebutuhan warga sekolah serta untuk menambah keuntungan sekolah. Sementara itu, kantin sekolah digunakan warga sekolah untuk mengisi waktu luang ketika jam istirahat atau jam kosong, baik untuk membeli makanan maupun minuman. Sedangkan persewaan mobil, digunakan untuk menambah pemasukan sekolah.

Bengkel AC mobil milik SMKN 6 Kota Malang merupakan bengkel yang didirikan atas dasar program pemerintah melalui Dirjen PSMK. Bengkel Tersebut juga disebut sebagai Teaching Factory. Bengkel AC mobil milik SMKN 6 Kota Malang digunakan untuk kegiatan belajar dan mengajar serta digunakan sebagai bisnis.

\section{Prosedur Pengelolaan Usaha Mandiri Sekolah di SMKN 6 Kota Malang}

SMKN 6 Kota Malang memiliki beragam jenis usaha mandiri sekolah. Dimulai dari bank sampah sekolah, business center school, hingga bengkel AC mobil. Di dalam pelaksanannya, masing-masing unit usaha mandiri sekolah memiliki kerjasama dengan pihak luar sekolah. Kerjasama tersebut dilakukan agar kedua belah pihak mendapatkan keuntungan.

Bank sampah sekolah milik SMKN 6 Kota Malang bekerjasama dengan Bank Sampah Malang untuk menjadi bank sampah unit. Sampah-sampah yang telah dipilah oleh bank sampah sekolah akan dikumpulkan dan ditimbang di Bank Sampah Malang. Sampah yang dikumpulkan di Bank Sampah Malang dapat ditukar dengan uang yang bisa dibagikan kepada nasabah (warga sekolah) sesuai dengan jumlah tabungan masing- masing.

Unit usaha mandiri sekolah lainnya adalah business center school. Unit usaha tersebut memiliki 3 jenis usaha. Yang pertama adalah Unit Produksi dan Jasa (UPJ). Modal yang digunakan berasal dari pusat dan dari hasil keuntungan bisnis. UPJ dikelola oleh 4 orang pengurus, yang terdiri dari 2 orang pemegang kebijakan dan 2 orang karyawan. Keuntungan dari bisnis UPJ digunakan untuk peningkatan dan pengembangan unit business center school serta akan digunakan untuk kesejahteraan guru dan karyawan (pengadaan seragam dan THR). Kerjasama yang dilakukan oleh Unit Produksi dan Jasa adalah dengan eSWe untuk penadaan LKS, Aice untuk es krim, dan Unggul untuk pengadaan dan servis mesin fotocopy. Jenis usaha lainnya dari business center school adalah kantin sekolah dan persewaan mobil. Untuk kantin sekolah, dikelola menggunakan sistem sewa pertahun. Harga sewa yang ditawarkan oleh sekolah adalah sebesar Rp.3.500.000 untuk unit kantin siswa, dan Rp. 5.500.000 untuk unit kantin guru dan karyawan. Sementara itu, persewaan mobil SMKN 6 Kota Malang dibuka untuk umum, dengan jam sewa dimulai dari pukul 06.00 WIB hingga pukul 22.00 WIB. Harga sewa yang ditawarkan adalah Rp. 600.000 untuk unit Elf, Rp. 300.000 untuk unit Kijang Innova, dan Rp. 150.000 untuk unit pickup.

Unit usaha mandiri yang terakhir adalah bengkel AC mobil. Bengkel Ac mobil milik SMKN 6 Kota Malang didirikan dengan bantuan dari Kemendikbud. Bengkel AC mobil dikelola oleh 5 orang pengurus yang wajib mengikuti magang di dunia industri selama 1 bulan agar dapat menjadi mekanik utama. Bengkel AC mobil dapat digunakan oleh guru otomotif untuk proses belajar dan mengajar. Bengkel AC mobil milik SMKN 6 Kota Malang dibuka untuk umum. Namun untuk semetara ini, belum ada list harga servis. Servis yang dilakukan bersifat gratis, namun akan dikenakan biaya apabila terdapat komponen/ sparepart yang harus diganti. Bengkel AC mobil dikelola oleh sekolah yang memiliki garis komando dari kepala sekolah, kurikulum, hingga jurusan. Bengkel AC mobil SMKN 6 Kota Malang bekerjasama dengan Toyota Auto 2000, yakni berupa penempatan 1 orang mekanik Auto 2000 di bengkel AC mobil SMKN 6 Kota Malang, serta pengarahan servis untuk dilakukan di bengkel AC mobil SMKN 6 Kota Malang apabila Bengkel Auto 2000 mengalami overloud.

\section{Indikator Kualitas/Mutu Sekolah di SMKN 6 Kota Malang}

Melalui bank sampah sekolah, SMKN 6 Kota Malang menjadi salah satu sekolah yang sangat dikenal oleh masyarakat secara luas. Selain SMKN 6 Kota Malang dikenal dengan sekolah adiwiyata, SMKN 6 Kota Malang juga terkenal pada bidang pengelolaan lingkungan. Banyak sekolah dan instansi yang melakukan kunjungan maupun pelatihan di SMKN 6 Kota Malang. 
Business Center School milik SMKN 6 Kota Malang merupakan unit usaha yang memberikan pelayanan pada bidang produksi dan jasa. Dengan adanya business center school, warga sekolah tidak perlu keluar sekolah apabila membutuhkan sesuatu yang berkaitan dengan ATK, pembelian buku, seragam, atau fotocopy. Selain itu, dengan adanya business center school dapat menambah pemasukan/ profit untuk sekolah.

Bengkel AC mobil SMKN 6 Kota Malang yang disebut juga sebagai Teaching Factory merupakan bengkel yang digunakan untuk proses belajar dan mengajar serta kegiatan bisnis. Khusus untuk proses belajar dan mengajar, bengkel AC mobil SMKN 6 Kota Malang memberi dampak positif berupa kemudahan dalam melakukan praktek. Peserta didik dapat mengetahui proses perbaikan secara riil pada mobil, tidak lagi menggunakan media praktek (trainer). Bengkel AC mobil memudahkan peserta didik dan guru dalam proses belajar mengajar.

\section{Faktor Penunjang dalam Pengelolaan Usaha Mandiri Sekolah di SMKN 6 Kota Malang}

Bank sampah sekolah milik SMKN 6 Kota Malang didirikan dengan berbagai alasan. Menariknya, adanya bank sampah sekolah dapat membantu peserta didik dan walimurid dalam membayar biaya pendidikan atau SPP. Uang yang didapat dari hasil menabung sampah akan diarahkan untuk pembayaran SPP, sehingga angka keterlambatan pembayaran/pelunasan SPP dapat diatasi.

Business center school didirikan dengan tujuan awal untuk memudahkan peserta didik memenuhi kebutuhannya. Kebutuhan tersebut berupa fotocopy, pembelian buku/LKS, ATK, seragam, dan sebagainya. Hal tersebut berkaitan dengan proses belajar dan mengajar, pengadaannya dapat dilakukan di dalam sekolah sehingga siswa tidak perlu keluar sekolah dan mengganggu kegiatan proses belajar danmengajar.

Bengkel AC mobil SMKN 6 Kota Malang didirikan atas program pemerintah. Bengkel tersebut mendapatkan bantuan dari Kementerian Pendidikan dan Kebudayaan yang digunakan untuk membuat bengkel Teaching Factory yang dikhususkan untuk bengkel AC mobil. Bengkel AC mobil selanjutnya dapat digunakan untuk proses belajar dan mengajar serta bisnis.

\section{Faktor Penghambat dalam Pengelolaan Usaha Mandiri Sekolah di SMKN 6 Kota Malang}

Proses mendirikan bank sampah sekolah tidak hanya menghadirkan dukungan saja. Terdapat pula tantangan yang menjadi faktor penghambat mendirikan bank sampah sekolah, dan tantangan tersebut harus dihadapi. Tantangan tersebut berupa stigma negatif terhadap bank sampah sekolah yang akan mengajarkan peserta didik untuk menjadi pemulung. Stigma negatif tersebut harus mampu terjawab oleh pengelola sekolah, khususnya pengelola bank sampah sekolah.

Bank sampah sekolah milik SMKN 6 Kota Malang juga memiliki hambatan lain. Hambatan tersebut berupa ketidakproduktifan bank sampah sekolah selama liburan dan musim hujan. Ketika memasuki liburan, tentu tidak ada kegiatan apapun. Sedangkan ketika musim hujan, banyak peserta didik yang malas mengumpulkan sampah.

Unit usaha business center school SMKN 6 Kota Malang tidak banyak mengalami hambatan. Hambatan hanya terjadi di jenis usaha kantin sekolah. Di kantin sekolah terdapat makanan dan minuman yang seharusnya tidak dijual. Hal tersebut dilihat dari segi bahan, kemasan, dan kesehatan. SMKN 6 Kota Malang terkenal dengan adiwiyata mandiri, sehingga apapun yang membahayakan kesehatan dan lingkungan harus bisa dicegah.

Bengkel AC mobil SMKN 6 Kota Malang adalah bengkel yang masih baru. Bengkel tersebut didirikan menjelang akhir tahun 2018, yakni pada bulan November. Hambatan yang terjadi adalah sistem administrasi yang belum berjalan dengan baik. Hal tersebut terjadi karena bengkel yang masih baru didirikan, sehingga belum terdapat evaluasi secara rinci terhadap bengkel AC mobil SMKN 6 KotaMalang. 


\section{Solusi untuk Mengatasi Faktor Penghambat Usaha Mandiri Sekolah di SMKN 6 Kota Malang}

Hambatan yang terjadi untuk bank sampah sekolah adalah datangnya liburan dan musim hujan. Solusi yang dapat dilakukan adalah menutup bank sampah sekolah agak tidak terjadi ketidakproduktifan, khususnya pada masa liburan. Bank sampah sekolah akan dibuka kembali seusai liburan.

Business center school SMKN 6 Kota Malang memiliki hambatan pada jenis usaha kantin sekolah, yakni penjualan makan dan minuman yang tidak sesuai aturan. Solusi yang dapat dilakukan adalah dengan cara melakukan pengawasan. Pengawasan dilakukan setiap 3 bulan 1x dan melibatkan UKS. Hal ini dilakukan dengan harapan tidak ada lagi penjual di kantin yang melakukan pelanggaran berupa menjual makanan dan minuman yang tidak sesuai aturan.

Sistem administrasi yang belum berjalan dengan baik merupakan hambatan yang terjadi pada unit usaha bengkel AC mobil. Solusi yang dapat dilakukan adalah dengan cara menetapkan jadwal secara rinci. Jadwal tersebut juga termasuk mekanik, guru, dan siswa yang bertugas. Hal tersebut dilakukan dengan harapan bengkel tidak kosong dan dapat terkelola dengan baik.

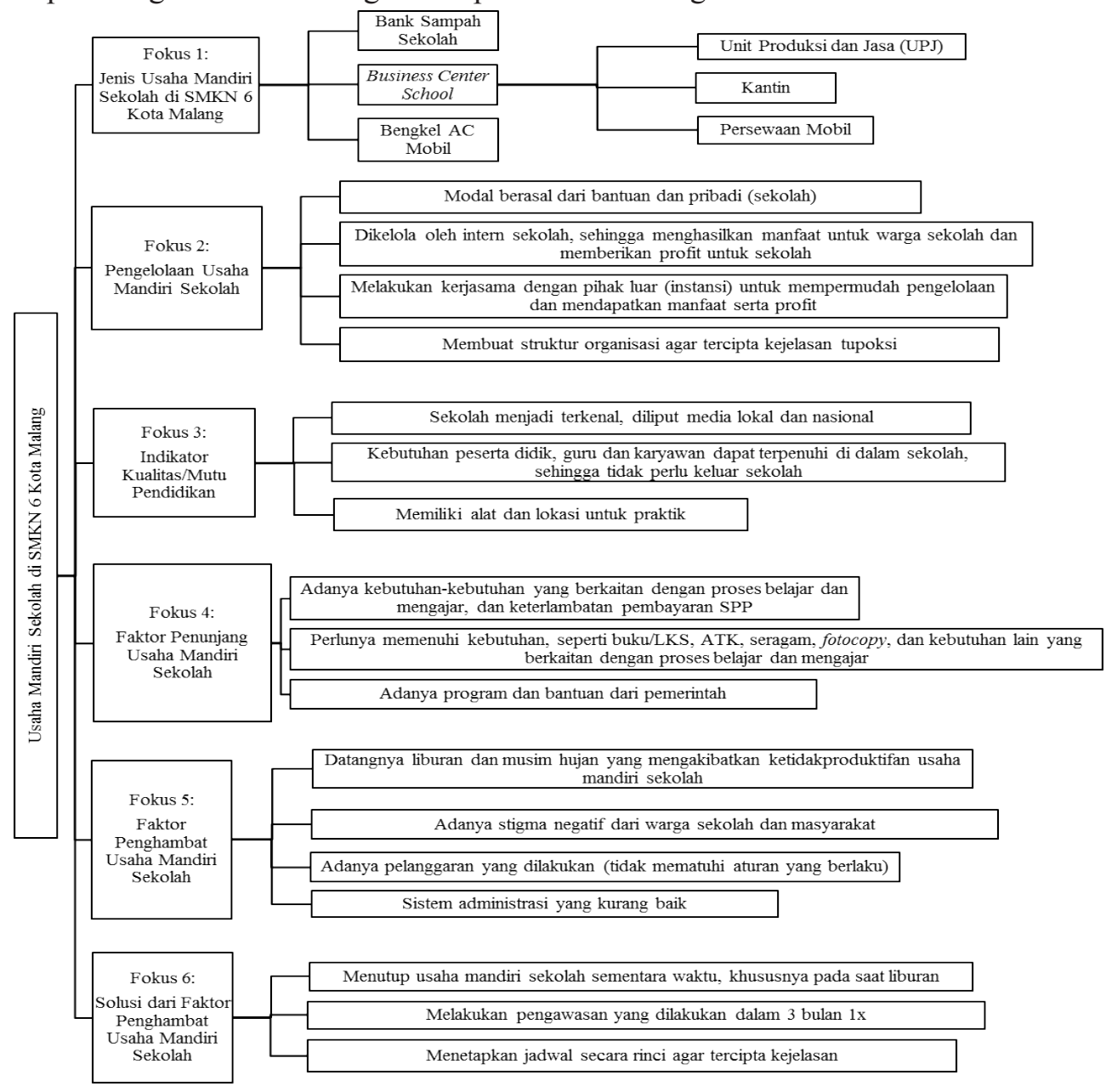

Gambar 1. Bagan Temuan Penelitian

\section{PEMBAHASAN}

\section{Jenis Usaha Mandiri Sekolah di SMKN 6 Kota Malang}

Bank sampah diharapkan dapat memberikan penyadaran bagi masyarakat sekolah akan pentingnya menjaga lingkungan dengan cara mengurangi jumlah sampah. Selain itu bank sampah juga diharapkan 
mampu untuk melatih masyarakat sekolah dalam berwirausaha, dimana dalam program bank sampah ini baik guru maupun siswa dapat mengumpulkan sampah yang kemudian ditimbang dan dapat ditukarkan dengan uang melalui Bank Sampah Kota Malang. Sementara itu, business center school dibentuk untuk memenuhi kebutuhan siswa, seperti fotocopy, alat tulis, seragam, dan lain sebagainya. Sehingga siswa di dalam kaitannya dengan proses belajar dan mengajar pengadaannya bisa dilakukan di UPJ tanpa harus mengganggu kegiatan PBM (keluar sekolah). Kemudian yaitu bengkel AC mobil, dibuat dengan dasar program pemerintah. Harapan dari adanya bengkel $\mathrm{AC}$ adalah siswa mampu mengetahui dunia industri (bengkel) tanpa harus ke luar sekolah, seperti Prakerin (Praktek Kerja Industri).

Pada dasarnya, usaha mandiri sekolah didirikan agar dapat memberikan manfaat. Setiap sekolah harus berupaya untuk menghasilkan keuntungan yang hasilnya dapat langsung dirasakan oleh peserta didik dan warga sekolah lainnya. Hal tersebut sesuai dengan pendapat Barnawi \& Arifin (2013) yang menyatakan bahwa setiap sekolah harus berorientasi pada keuntungan (profit oriented). Maksudnya adalah pandangan atau perhatian guru untuk mengupayakan keuntungan dari proses pendidikan di sekolah. Keuntungan tersebut yaitu keuntungan secara kognitif, afektif, psikomotorik, dan keuntungan yang berupa produk fisik juga. Profit oriented disini bukanlah menjadikan sekolah sebagai lahan bisnis yang mengutamakan keuntungan dan mengesampingkan kualitas pendidikan. Namun profit oriented disini diterapkan guna menghasilkan keuntungan dari proses pendidikan yang hasilnya dapat dirasakan langsung oleh peserta didik dan warga sekolah lainnya.

\section{Prosedur Pengelolaan Usaha Mandiri Sekolah di SMKN 6 Kota Malang}

SMKN 6 Kota Malang mampu mengelola usaha mandiri sekolah dengan cukup baik, sebab mereka memiliki modal dan hubungan kerjasama yang baik dengan pihak industri. Hal tersebut dibuktikan dengan adanya kerjasama dengan beberapa pihak seperti Toyata Auto 2000, Bank Sampah Malang, Aice, eSWe, dan Unggul. Hubungan kerjasama tersebut juga diimbangi dengan pengelolaan usaha dengan baik dan benar.

Bank sampah SMKN 6 Kota Malang bekerjasama dengan Bank Sampah Malang. Kerjasama tersebut menghasilkan kegiatan positif berupa penyadaran masyarakat akan pentingnya menjaga kebersihan/ lingkungan. Hal tersebut juga menghasilkan sesuatu yang lebih bermanfaat lagi, yakni menghasilkan uang yang dapat digunakan untuk membayar SPP bagi peserta didik. Sementara itu, business center school bekerjasama dengan Aice untuk pengadaan es krim, eSWe untuk pengadaan buku LKS, dan Unggul untuk pengadaan dan servis mesin fotocopy. Kerjasama tersebut mampu memudahkan kinerja dari unit usaha business center school dalam berkegiatan dan memperoleh keuntungan. Sedangkan bengkel AC mobil milik SMKN 6 Kota Malang bekerjasama dengan Toyota Auto 2000 dalam pelaksanaan kegiatannya. Kerjasama tersebut berupa pelatihan untuk guru yang akan menjadi mekanik bengkel serta menjadikan bengkel AC mobil milik SMKN 6 Kota Malang sebagai bengkel rujukan apabila bengkel Toyota Auto 2000 mengalami overloud.

Pengelolaan usaha mandiri sekolah juga setidaknya mengacu pada standar nasional pendidikan. Untuk jenjang SMK/MAK, standar tersebut mengacu pada Permendikbud Nomor 34 Tahun 2018 tentang Standar Nasional Pendidikan Sekolah Menengah Kejuruan/Madrasah Aliyah Kejuruan. Standar tersebut menjadi acuan dari 8 standar pendidikan yang harus dipenuhi oleh suatu sekolah. Permendikbud Nomor 34 Tahun 2018 tentang Standar Nasional Pendidikan Sekolah Menengah Kejuruan/Madrasah Aliyah Kejuruan menyatakan kemampuan lulusan pendidikan kejuruan yang diharapkan adalah memiliki kompetensi yang dibutuhkan oleh dunia usaha/industri. Konsekuensinya, pendidikan kejuruan membutuhkan fasilitas serta bahan dan alat habis pakai untuk kegiatan pencapaian kompetensi lulusan lebih banyak. Hal tersebut menyebabkan suatu sekolah harus melakukan pengelolaan secara baik agar dapat memenuhi segala kebutuhan yang ada. Salah satu kegiatan pengelolaan sekolah yang baik adalah dengan cara menciptakan usaha mandiri sekolah yang juga bekerjasama dengan pihak luar/industri. Kegiatan tersebut perlu dilakukan untuk mengembangkan finansial sekolah serta memenuhi fasilitas yang dibutuhkan oleh sekolah. 
Mengelola suatu usaha mandiri sekolah juga tidak lepas kaitannya dengan manajemen. Manajemen adalah pusat kekuatan berpikir (think thank) yang berfungsi sebagai mesin penggerak, alat yang aktif dan efektif untuk mengatur unsur-unsur pembentuk sistem sehingga terorganisasikan dan bekerja secara efektif dan efisien untuk tujuan yang diharapkan (Kurniadin \& Machali, 2012). Manajemen juga dapat diartikan sebagai usaha kerjasama yang dilakukan oleh 2 orang atau lebih dengan cara memaksimalkan segala sumberdaya yang ada guna mencapai tujuan yang telah ditetapkan. Dengan demikian, manajemen dapat diartikan sebagai suatu usaha yang dilakukan untuk mencapai tujuan secara efektif danefisien.

\section{Indikator Kualitas/Mutu Sekolah di SMKN 6 Kota Malang}

Usaha mandiri sekolah di SMKN 6 Kota Malang memiliki 3 jenis usaha yang masing-masing mampu memberikan dampak positif bagi sekolah, peserta didik, dan warga sekolah lainnya. Melalui bank sampah sekolah, SMKN 6 Kota Malang dapat memberikan peluang peserta didik untuk mendapatkan uang yang bisa digunakan untuk membayar SPP. Bank sampah sekolah juga menyebabkan SMKN 6 Kota Malang dikenal secara luas melalui berbagai media. Sementara itu, melalui business center school, SMKN 6 Kota Malang mampu memfasilitasi peserta didik dan warga sekolah lainnya untuk memenuhi segala kebutuhannya. Sedangkan melalui bengkel AC mobil, peserta didik dan guru dapat melakukan kegiatan belajar dan mengajar dengan baik tanpa harus keluar sekolah. Adanya bengkel AC mobil juga akan memberikan financial profit, sebab bengkel AC tersebut juga akan digunakan untuk bisnis.

Permendikbud Nomor 34 Tahun 2018 tentang Standar Nasional Pendidikan Sekolah Menengah Kejuruan/Madrasah Aliyah Kejuruan tentu akan menjadi indikator kualitas pendidikan SMK. Namun, pemasaran jasa pendidikan juga berkaitan dengan upaya menciptakan sekolah yang berkualitas. Indradjaja dan Karno (dalam Wijaya, 2012) menyebutkan bahwa pemasaran jasa pendidikan mutlak diperlukan karena hal-hal berikut ini:

1. Sekolah yang kita kelola masih tetapeksis.

2. Jasa pendidikan yang kita lakukan relevan dengan kebutuhanmereka.

3. Jenis jasa pendidikan yang kita lakukan dapat dikenal dandipahami.

4. Eksistensi sekolah tidakditinggalkan.

Secara umum, mutu mengandung makna derajat (tingkat) keunggulan suatu produk (hasil kerja/ upaya) baik berupa barang maupun jasa, baik yang tangible maupun yang intangible (Zazin, 2017). Sementara itu, menurut Peters dan Austin (dalam Zazin, 2017), mutu adalah sebuah hal yang berhubungan dengan gairah dan harga diri. Menurut Deming (dalam Zazin, 2017), mutu berarti pemecahan untuk mencapai penyempurnaan terus menerus. Dalam dunia pendidikan, yang dapat diterapkan adalah: (1) anggota dewan sekolah dan administrator harus menetapkan tujuan pendidikan; (2) menekankan pada upaya kegagalan pada siswa; (3) menggunakan metode kontrol statistik untuk membantu memperbaiki outcome siswa dan administratif.

Berbeda dengan Juran (dalam Zazin, 2017), mutu diartikan sebagai kesesuaian penggunaan atau tepat untuk dipakai. Pendekatannya adalah orientasi pada pemenuhan kebutuhan pelanggan, dengan beberapa pandangannya: (1) meraih mutu merupakan proses yang tidak kenal akhir; (2) perbaikan mutu merupakan proses yang berkesinambungan; (3) mutu memerlukan kepemimpinan dari anggota dewan sekolah dan administratif; (4) prasyarat mutu adalah adanya pelatihan seluruh warasekolah.

\section{Faktor Penunjang dalam Pengelolaan Usaha Mandiri Sekolah di SMKN 6 Kota Malang}

Sebagian besar usaha mandiri sekolah di SMKN 6 Kota Malang didirikan atas dasar yang sama, yakni memenuhi kebutuhan maupun keadaan yang sedang berlangsung. Bank sampah sekolah hadir untuk membantu peserta didik dalam membayar SPP. Sedangkan business center school hadir untuk memfasilitasi kebutuhan peserta didik maupun warga sekolah lainnya. Hal tersebut merupakan faktorfaktor penunjang didirikannya usaha mandiri sekolah dan bertahan hingga saat ini. Unit usaha lainnya yang dimiliki oleh SMKN 6 Kota Malang adalah bengkel AC mobil. Bengkel AC mobil didirikan atas dasar program pemerintah melalui Dirjen PSMK. Bengkel tersebut akan digunakan untuk Teaching 
Factory, yaitu untuk proses belajar dan mengajar di sekolah menggunakan alat praktek langsung berupa kendaraan, bukan dengan alat peraga (trainer). Namun bengkel AC mobil milik SMKN 6 Kota Malang tidak hanya digunakan untuk kegiatan belajar dan mengajar saja, bengkel tersebut juga digunakan untuk bisnis, yaitu menerima jasa servis AC mobil untukumum.

Segala faktor yang mendorong adanya usaha mandiri sekolah di SMKN 6 Kota Malang juga memiliki kaitan dengan pemasaran jasa pendidikan. Lockhart (dalam Wijaya, 2012) menyebutkan lima faktor yang mendorong timbulnya pemasaran jasa pendidikan, sebagai berikut:

1. Meningkatnya Kompetisi.

Kita perlu memasarkan sekolah agar mendapatkan siswa yang potensial.

2. PerubahanDemografi.

Pemasaran jasa pendidikan dapat membantu kita untuk menilai kebutuhan masyarakat, menambah sumber daya tambahan, dan menciptakan program pendidikan sesuai dengan kebutuhan masyarakat.

3. Ketidak percayaan Masyarakat.

Banyak masyarakat menilai bahwa sekolah negeri memiliki standar yang lebih tinggi, akuntabilitas lebih besar, gaji guru berdasarkan kinerja, serta persyaratan gelar guru lebih tinggi dibandingkan dengan sekolah swasta. Akhirnya, banyak sekolah negeri menjadi korban dari kesalahan masyarakat tersebut.

4. PenyelidikanMedia.

Hubungan dengan media merupakan bagian penting dari program pemasaran jasa pendidikan.

5. Keterbatasan Sumberdaya.

Pemasar jasa pendidikan harus merancang program pemasaran jasa pendidikan yang mampu memelihara hubungan suportif dengan masyarakat agar sekolah menghasilkan dana tambahan sehingga dapat melayani masyarakat dengan baik.

\section{Faktor Penghambat dalam Pengelolaan Usaha Mandiri Sekolah di SMKN 6 Kota Malang}

Usaha mandiri sekolah yang dimiliki oleh SMKN 6 Kota Malang tidak selalu berjalan dengan mulus. Hal tersebut disebabkan adanya faktor yang menghambat jalannya usaha mandiri sekolah. Faktorfaktor tersebut yaitu adanya ketidaksetujuan terkait didirikannya unit usaha mandiri sekolah, kegiatankegiatan yang melanggar aturan, dan berjalannya sistem yang kurang baik. Hal tersebut didapat dari unit usaha bank sampah sekolah yang mengalami pro dan kotra. Ketidaksetujuan didirikannya bank sampah lahir dari beberapa pihak yang menyatakan bahwa bank sampah akan mengajarkan peserta didik untuk menjadi pemulung. Namun permasalahan utama dari bank sampah lahir dari sistem yang berjalan kurang baik. Hal tersebut mengakibatkan tidak produktifnya bank sampah ketika musim liburan. Sementara itu, business center school mengalami adanya pelanggaran-pelanggaran dari unit usaha kantin, yaitu menjual makanan yang membahayakan kesehatan. Tentu hal tersebut merupakan kegiatan yang melanggar aturan yang telah dibuat. Selanjutnya adalah bengkel AC mobil yang memiliki faktor penghambat yaitu berjalannya sistem yang kurang baik. Hal tersebut dapat dilihat dari sepinya bengkel serta sistem administrasi yang belum siap berjalan.

Faktor-faktor penghambat jalannya usaha mandiri sekolah di SMKN 6 Kota Malang selaras dengan teori yang dijelaskan oleh Deming. Deming (dalam Sallis, 2015) menyebutkan bahwa terdapat beberapa penyebab kegagalan mutu yang dibedakan menjadiduabentuk,yaituumumdankhusus.Sebab-sebab umum adalah sebab - sebab yang diakibatkan oleh kegagalan sistem. Masalah sistem ini merupakan masalah internal proses institusi. Masalah-masalah tersebut hanya bisa diatasi jika sistem, proses, dan prosedur institusi tersebut diubah. Sementara sebab-sebab lain yang ia sebut sebagai "sebab khusus" melahirkan variasi-variasi yang nonacak di dalam sistem dan merupakan sebab-sebab eksternal.

Penyebab umum mutu pendidikan menjadi rendah dapat disebabkan oleh beberapa sumber yang mencakup desain kurikulum yang lemah, bangunan yang tidak mematuhi syarat, lingkungan kerja yang buruk, sistem dan prosedur yang tidak sesuai, jadwal kerja yang serampangan, sumber daya yang kurang, dan pengembangan staf yang tidak memadai (Sallis, 2015). Untuk menentukan akar 
dan penyebaran sebuah masalah, diperlukan sebuah upaya untuk mencari data-data kegagalan dan melakukan pemeriksaan secara teratur. Dan, kesalahan yang sering terjadi dalam dunia pendidikan adalah kurangnya penelitian dan analisis sebab-sebab rendahnya tingkat pencapaian tujuan, serta belum terwujudnya penelitian dan analisis tersebut sebagai subjek aksi manajerial (Sallis, 2015).

Di sisi lain, sebab-sebab khusus kegagalan sering diakibatkan prosedur dan aturan yang tidak diikuti atau ditaati, meskipun kegagalan tersebut mungkin juga diakibatkan oleh kegagalan komunikasi atau kesalahpahaman. Kegagalan tersebut bisa juga disebabkan oleh anggota individu staf yang tidak memiliki skill, pengetahuan, dan sifat yang dibutuhkan untuk menjadi seorang guru atau manajer pendidikan. Sebab-sebab khusus masalah mutu bisa mencakup kurangnya pengetahuan, keterampilan anggota, dan motivasi, serta kegagalan komunikasi atau masalah yang berkaitan dengan perlengkapan (Sallis,2015).

\section{Solusi untuk Mengatasi Faktor Penghambat Usaha Mandiri Sekolah di SMKN 6 KotaMalang}

Adanya faktor-faktor yang menghambat jalannya usaha mandiri sekolah tentu akan melahirkan solusi-solusi yang cocok untuk diterapkan. Berdasarkan masalah atau hambatan yang ada, SMKN 6 Kota Malang memiliki solusi-solusi alternatif, yaitu menutup sementara unit usaha, melakukan pengawasan, serta memperbaiki sistem. Hal tersebut telah dilakukan guna mengatasi masalah/hambatan dari jalannya usaha mandiri sekolah.

Menjalankan solusi-solusi dari adanya masalah/hambatan dalam mendirikan/menjalankan usaha mandiri sekolah merupakan suatu keharusan. Sebab, hal tersebut akan berdampak pada mutu/kualitas sekolah. Hal tersebut selaras dengan Suhardan, dkk (2014), yang menyatakan bahwa mutu pendidikan merupakan prestasi terbaik yang diharapkan dapat dicapai oleh lembaga penyelenggara pendidikan, ia berupa prestasi yang tidak boleh kurang dari standar, bahkan harus melebihi standar yang ditetapkan. Kualitas/mutu pendidikan sangat erat kaitannya dengan harapan dan kepuasan konsumen, yakni peserta didik dan orangtua/walimurid. Dengan demikian, sekolah yang memiliki kualitas/mutu yang baik akan menciptakan sebuah kepuasan terhadap harapan- harapan yang diinginkan oleh konsumen. Kualitas/ mutu merupakan jaminan yang memiliki nilai jual dan nilai guna yang tinggi.

\section{SIMPULAN DAN SARAN}

\section{Simpulan}

Jenis usaha mandiri sekolah yang dimiliki oleh SMKN 6 Kota Malang ada 3, yaitu bank sampah sekolah, business center school, dan bengkel AC mobil. Semua unit usaha mandiri sekolah milik SMKN 6 Kota Malang terletak di dalam wilayah sekolah. Terdapat beberapa titik yang menjadi lokasi usaha mandiri sekolah. Pendirian usaha mandiri sekolah menggunakan modal pribadi (dari sekolah). Namun terdapat beberapa unit usaha mandiri sekolah yang mendapat bantuan dari pemerintah, seperti bengkel AC mobil. Usaha mandiri sekolah di SMKN 6 Kota Malang dikelola oleh internal sekolah, mulai dari kepala sekolah, guru, dan karyawan. Terdapat pula struktur organisasi yang dibuat dengan tujuan memiliki tupoksi yang jelas untuk masing-masing pengelola/anggota. Indikator kualitas sekolah di SMKN 6 Kota Malang ditunjukkan dengan terkenalnya SMKN 6 Kota Malang. Hal tersebut ditunjukkan dengan munculnya SMKN 6 Kota Malang di media lokal dan media nasional. SMKN 6 Kota Malang juga memiliki unit penunjang kebutuhan warga sekolah, sehingga warga sekolah tidak keluar dari wilayah sekolah untuk memenuhi kebutuhannya dan tidak mengganggu proses belajar dan mengajar.

Faktor penunjang adanya usaha mandiri sekolah di SMKN 6 Kota Malang adalah warga sekolah yang membutuhkan alat (usaha mandiri sekolah) untuk memenuhi kebutuhannya, baik yang menunjang ekonomi pendidikan maupun keperluan proses belajar dan mengajar. Perlunya memenuhi kebutuhan, seperti buku/LKS, ATK, seragam, fotocopy, dan kebutuhan lain yang berkaitan dengan proses belajar dan mengajar juga menjadi faktor penunjang adanya usaha mandiri sekolah di SMKN 6 Kota Malang. 
Selain itu, usaha mandiri sekolah juga didirikan atas dasar program pemerintah, seperti bengkel AC mobil. Sementara itu, faktor penghambat dari usaha mandiri sekolah di SMKN 6 Kota Malang yaitu berupa penentangan terhadap proses pendirian usaha mandiri sekolah, khususnya bank sampah sekolah. Kegiatan yang tidak produktif, adanya pelanggaran, dan sistem pengadministrasian yang tidak berjalan dengan baik juga menjadi hambatan usaha mandiri sekolah. Selain itu, terdapat pula pihak-pihak yang melanggar aturan yang telah dibuat. Dalam mengatasi faktor-faktor penghambat usaha mandiri sekolah, terdapat beberapa solusi yang diterapkan. Usaha mandiri sekolah yang tidak produktif akan ditutup sementara waktu agar produktivitas kegiatan tidak rendah. Selain itu, pengawasan terhadap usaha mandiri sekolah juga perlu dilakukan agar tidak terjadi ketidaksesuaian. Kemudian, penetapan jadwal secara rinci perlu dilaksanakan agar tidak terjadi kekosongan pada unit usaha mandiri sekolah.

\section{Saran}

Berdasarkan penelitian tersebut terdapat saran yang ditujukan kepada beberapa pihak. Yang pertama Kepala Cabang Dinas Pendidikan Provinsi Jawa Timur Wilayah Malang-Batu, agar selalu mengupayakan usaha mandiri sekolah untuk berdiri dan berkembang guna membantu, memfasilitasi, dan memenuhi segala kebutuhan peserta didik, warga sekolah, dan masyarakat sekitar. Yang kedua Kepala SMKN 6 Kota Malang, agar selalu meningkatkan pengawasan pada usaha mandiri sekolah agar bisa berkembang dan lebih baik hingga tercapainya tujuan pendidikan di SMKN 6 Kota Malang. Yang ketiga Komite SMKN 6 Kota Malang, agar selalu membantu upaya peningkatan kualitas pendidikan melalui usaha mandiri sekolah di SMKN 6 Kota Malang. Yang keempat Ketua Jurusan Administrasi Pendidikan, agar menjadikan penelitian ini sebagai salah satu referensi tema penelitian mahasiswa yang berkaitan dengan pengelolaan usaha mandiri sekolah, serta menjaga kerjasama dengan SMKN 6 Kota Malang guna pelaksanaan penelitian. Yang kelima peneliti selanjutnya, agar melakukan penelitian berkaitan dengan usaha mandiri sekolah di sekolah menengah kejuruan lainnya. Hal ini dikarenakan keterbatasan penulis dalam segi kemampuan dan waktu untuk melakukan penelitian berkaitan dengan haltersebut.

\section{DAFTAR RUJUKAN}

Barnawi \& Arifin, M. (2013). Mengelola Sekolah Berbasis Entrepreneurship. Jogjakarta: Ar Ruzz Media.

Kurniadin, D. \& Machali, I. (2012). Manajemen Pendidikan: Konsep \& Prinsip Pengelolaan Pendidikan. Jogjakarta: Ar Ruzz Media.

Peraturan Menteri Pendidikan dan Kebudayaan Nomor 34 Tahun 2018 tentang Standar Nasional Pendidikan Sekolah Menengah Kejuruan/Madrasah Aliyah Kejuruan. Datadikdasmen, (Online), (www.datadikdasmen. com), diakses 4 April 2019.

Sallis, E. (2015). Total Quality Management in Education: Model, Teknik, dan Implementasinya. Terjemahan Ahmad Ali Riyadi dan Fahrurrozi. Yogyakarta: IRCiSoD. 2002.

Suhardan, D., Riduwan, \& Enas. (2014). Ekonomi dan Pembiayaan Pendidikan. Bandung: Alfabeta.

Wijaya, D. (2012). Pemasaran Jasa Pendidikan: Mengapa Sekolah Memerlukan Marketing?. Jakarta: Salemba Empat.

Zazin, N. (2017). Gerakan Menata Mutu Pendidikan: Teori \& Aplikasi. Jogjakarta: Ar Ruzz Media. 